\title{
Significance of the detection of beta-galactosidase and of beta-xylosidase in the taxonomic study of the genus Haemophilus
}

\author{
W. HANSEN, E. SCHOUTENS, AND E. YOURASSOWSKY \\ From the Service de Biologie Clinique, Hôpital Universitaire Brugmann, Avenue J.-J. Crocq 1, 1020 \\ Brussels, Belgium
}

SUMmARY A total of 314 strains of Haemophilus, isolated from clinical samples, were studied for the production of beta-galactosidase and beta-xylosidase. None of the $H$. influenzae strains studied ( 9 beta-lactamase positive strains and 129 beta-lactamase negative strains) possessed these enzymes. Both enzymes were almost constantly observed among strains of $H$. paraphrophilus (10 strains studied) and of $\boldsymbol{H}$. paraphrohaemolyticus (9 strains studied). Among the other species (H. parainfluenzae, 55 strains; $\boldsymbol{H}$. haemolyticus, 5 strains; $\boldsymbol{H}$. parahaemolyticus, 97 strains), beta-galactosidase was present in about $30 \%$ of the strains studied whereas beta-xylosidase was detected occasionally $(3 \%$ of the strains studied). Detection of these two enzymes could be a valuable test for the taxonomic study of the genus Haemophilus. However, the type of substrate used for the detection of betaxylosidase is important: use of the para-nitro-phenyl-beta-xylopyranoside yielded more positive results than the use of its ortho-isomer.

The significance of the detection of beta-galactosidase among Enterobacteriaceae and other Gramnegative bacilli has been reported by Le Minor and Ben Hamida (1962) and Lapage et al. (1973). The beta-xylosidase activity of different groups of bacteria has previously been examined and its interest outlined by Brisou et al. (1972), Hansen et al. (1977), Kilian and Bülow (1976), Lajudie and de Barjac (1976), and Richard (1973).

The present study was undertaken to evaluate the taxonomic significance of the detection of these enzymes among the genus Haemophilus.

\section{Material and methods}

\section{ORGANISMS}

During a systematic search conducted in 1976 for the detection of beta-lactamase producing strains, a total of 305 strains of Haemophilus were consecutively isolated on a selective medium previously described (Hansen et al., 1973). Strains were collected mainly from specimens from the respiratory tract and the ears of hospital inpatients. They included 129 strains of $H$. influenzae, 55 strains of $H$. parainfluenzae, 5

Received for publication 20 March 1979 strains of $H$. haemolyticus, 97 strains of $H$. parahaemolyticus, 10 strains of $H$. paraphrophilus, and 9 strains of $H$. paraphrohaemolyticus. Nine additional beta-lactamase positive strains of $H$. influenzae were kindly provided by Dr R. B. Sykes (Glaxo Research, Greenford: 8 strains) and by Dr P. Piot (Institut de Médicine Tropicale, Antwerp: 1 strain).

METHODS OF EXAMINATION

Identification of the strains was based on morphology, requirement for growth factors (using BBL disks containing either or both of the two $\mathrm{X}$ and $\mathrm{V}$ growth factors), and haemolytic activity examined after growth on $5 \%$ defibrinated horse blood in Heart Infusion Agar (Difco) supplemented with 5\% Fildes enrichment (Difco). Additional tests were performed according to the techniques described by Zinnemann et al. $(1968,1971)$ for characterisation of the species described by these authors. The Haemophilus strains were assigned to species according to the taxonomy proposed by Zinnemann and Biberstein (1974).

Detection of beta-xyloside xylohydrolase (betaxylosidase) was performed according to the method of Brisou et al. (1972) using, as did these authors, the para-nitro-phenyl-beta-xylopyranoside (PNPX) 
rather than its ortho-isomer, because of its better solubility. A heavy suspension of cells grown on Heart Infusion Agar (Difco) supplemented with 5\% Fildes enrichment (Difco) was made in test tubes containing $0.5 \mathrm{ml}$ sterile water and incubated for 24 hours at $37^{\circ} \mathrm{C}$ in the presence of a PNPX disk prepared in our laboratory as follows. Paper disks ( $1 \mathrm{~cm}$ diameter) were covered with $0.05 \mathrm{ml}$ of a $1 \%$ aqueous solution of PNPX and kept cool $\left(+4^{\circ} \mathrm{C}\right)$ after drying. A yellow colour was indicative of a positive test. Beta-D-galactoside-galactohydrolase (beta-galactosidase) was detected by means of the same technique, an ONPG disk (Bio-Merieux) being substituted for the PNPX disk.

Beta-lactamase production was determined according to the method of Kammer et al. (1975), originally described by O'Callaghan et al. (1972), by means of the Glaxo chromogenic compound 87/312.

\section{Results}

As shown in the Table, two of the $\mathbf{3 0 5}$ wild strains studied produced beta-lactamase; both were typical strains of $\boldsymbol{H}$. parainfluenzae.

All strains of $H$. influenzae lacked beta-galactosidase; this enzyme was often present in strains of $H$. parainfluenzae $(42 \%$ of the strains tested), of $H$. haemolyticus (3/5) and of $H$. parahaemolyticus ( $23 \%$ of the strains tested). All 10 strains of $H$. paraphrophilus and all nine of $H$. paraphrohaemolyticus were beta-galactosidase positive.

All strains of $\boldsymbol{H}$. influenzae and $\boldsymbol{H}$. haemolyticus lacked beta-xylosidase. Occasional strains of $H$. parainfluenzae $(2 / 55)$ and of $H$. parahaemolyticus (3/97) possessed this enzyme. In contrast, most strains of $H$. paraphrophilus $(9 / 10)$ and all strains of $H$. paraphrohaemolyticus were beta-xylosidase positive.

Among the beta-lactamase positive strains, the nine strains of $H$. influenzae lacked the two other enzymes; the two strains of $H$. parainfluenzae possessed beta-galactosidase but lacked betaxylosidase.

\section{Discussion}

Detection of beta-galactosidase and of betaxylosidase among the genus Haemophilus is of considerable taxonomic value. $H$. influenzae, whether producing beta-lactamase or not, always lacked these two enzymes, as already pointed out by Khramova and Andreeva (1975), Kilian (1976), and Lapage et al. (1973) for beta-galactosidase, and by Kilian (1976) for beta-xylosidase. However, Khramova and Andreeva (1975) detected betagalactosidase among strains of $\boldsymbol{H}$. aegyptius, a species considered by Kilian et al. (1976) as a haemagglutinating variant of $H$. influenzae biotype III.

Among strains of $H$. parainfluenzae, 23/55 (42\%) possessed beta-galactosidase whereas beta-xylosidase was detected in only $2 / 55$ strains tested. These results are not in good agreement with those obtained by other workers. Lapage et al. (1973), who tested only three strains, did not detect beta-galactosidase, whereas Khramova and Andreeva (1975) and Kilian (1976) found it, respectively, in $100 \%$ and $82 \%$ of their strains. However, comparison between our results and those of Kilian is difficult as this author recognises only one species of $H$. parainfluenzae, among which he classes several types of V-dependent species $(H$. parainfluenzae, $H$. parahaemolyticus, and $H$. paraphrohaemolyticus) without taking into account the haemolytic activity and/or the $\mathrm{CO}_{2}$ requirements of his strains.

In our experience, strains of $H$. parahaemolyticus behave as strains of $H$. parainfluenzae: $23 \%$ possessed beta-galactosidase, and $3 \%$ beta-xylosidase. We cannot compare these results with those of others: Lapage et al. (1973) studied only one strain, and Kilian (1976), as pointed out above, did not distinguish $H$. parahaemolyticus from $H$. parainfluenzae.

$H$. haemolyticus, a species seldom isolated, was represented by only five strains. All lacked betaxylosidase; in contrast, three of them showed betagalactosidase activity. Results of the latter test in the

Table Enzymatic characteristics of 314 Haemophilus strains

\begin{tabular}{|c|c|c|c|c|}
\hline Species & $\begin{array}{l}\text { No. of strains } \\
\text { examined }\end{array}$ & $\begin{array}{l}\beta \text {-lactamase } \\
\text { positive }\end{array}$ & $\begin{array}{l}\beta \text {-galactosidase } \\
\text { positive }\end{array}$ & $\begin{array}{l}\beta \text {-xylosidase } \\
\text { positive }\end{array}$ \\
\hline \multicolumn{5}{|l|}{ H. influenzae } \\
\hline Wild strains & 129 & 0 & 0 & $\mathbf{0}$ \\
\hline $\begin{array}{l}\beta \text {-lactamase positive } \\
\text { Control strains }\end{array}$ & 9 & 9 & 0 & 0 \\
\hline$H$. parainfluenzae & 55 & 2 & 23 & 2 \\
\hline H. haemolyticus & 5 & $\mathbf{0}$ & 3 & $\mathbf{0}$ \\
\hline H. parahaemolyticus & 97 & 0 & 22 & 3 \\
\hline H. paraphrophilus & 10 & 0 & 10 & 9 \\
\hline H. paraphrohaemolyticus & 9 & 0 & 9 & 9 \\
\hline
\end{tabular}


literature are conflicting: Kilian (1976) did not detect this enzyme among his nine strains, Lapage et al. (1973) found it in one of two strains studied, and Khramova and Andreeva (1975) were able to demonstrate it in almost all their strains.

Detection of both enzymes has the greatest taxonomic significance among strains of $H$. paraphrophilus and of $H$. paraphrohaemolyticus. As these two species always possess beta-galactosidase and nearly all beta-xylosidase, demonstration of both enzymes in a strain of Haemophilus strongly suggests its appurtenance to one of these species.

It is noteworthy that Kilian (1976) could detect only one beta-xylosidase positive strain (a strain of $H$. haemoglobinophilus isolated from a pig) among the 426 strains of Haemophilus he studied, whereas we found this enzymatic activity in 23 of the 305 strains we tested. Several factors could explain this discrepancy: use of fresh isolates instead of collection strains, geographic distribution of different strains, and variations in methodology. The latter, in particular, must be kept in mind: we noted that four strains of $H$. paraphrophilus, which were beta-xylosidase positive when tested by the technique used in the present work, lacked this enzyme when the ortho-isomer was used instead of PNPX. We made the same observation among strains of Acinetobacter (unpublished data). Moreover, Brisou et al. (1972), using the PNPX for detecting betaxylosidase among Enterobacteriaceae, obtained a higher percentage of positive strains than Kilian and Bülow (1976), who used the ortho-isomer.

This points to the need for uniformity of the techniques applied in the taxonomic study of bacteria, particularly when the bacteria constitute a group as complex as the genus Haemophilus.

\section{References}

Brisou, B., Richard, C., and Lenriot, A. (1972). Intérêt taxonomique de la recherche de la $\beta$-xylosidase chez les 'Enterobacteriaceae'. Annales de l'Institut Pasteur, 123, 341-347.

Hansen, W., Blogie, M., Schoutens, E., and Yourassowsky, E. (1973). Un milieu sélectif pour l'isolement des Haemophilus dans les produits pathologiques des voies respiratoires. Annales de Biologie Clinique, 31, 47-51.

Hansen, W., Schoutens, E., and Yourassowsky, E. (1977). Taxonomy of Acinetobacter: the usefulness of $\beta$-D-xyloside xylohydrolase for strain differentiation. Journal of Clinical Pathology, 30, 838-841.

Kammer, R. B., Preston, D. A., Turner, J. R., and Hawley, L. C. (1975). Rapid detection of ampicillin- resistant Haemophilus influenzae and their susceptibility to sixteen antibiotics. Antimicrobial Agents and Chemotherapy, 8, 91-94.

Khramova, N. I., and Andreeva, Z. M. (1975). Characteristics of some species of microorganisms referred to the haemoglobinophil genus. (In Russian). Zhurnal Mikrobiologii, Epidemiologii i Immunobiologii, 52, 126129.

Kilian, M. (1976). A taxonomic study of the genus Haemophilus, with the proposal of a new species. Journal of General Microbiology, 93, 9-62

Kilian, M., and Bülow, P. (1976). Rapid diagnosis of Enterobacteriaceae. I. Detection of bacterial glycosidases. Acta Pathologica et Microbiologica Scandinavica, 84B, 245-251.

Kilian, M., Mordhorst, C. H., Dawson, C. R., and Lautrop, H. (1976). The taxonomy of Haemophili isolated from conjunctivae. Acta Pathologica et Microbiologica Scandinavica, 84B, 132-138.

Lajudie, J., and de Barjac, H. (1976). Recherche de certaines glycosidases chez 22 espèces du genre Bacillus. Annales de Microbiologie, 127A, 317-321.

Lapage, S. P., Efstratiou, A., and Hill, L. R. (1973). The orthonitrophenol (ONPG) test and acid from lactose in Gram-negative genera. Journal of Clinical Pathology, 26, 821-825.

Le Minor, L., and Ben Hamida, F. (1962). Avantages de la recherche de la $\beta$-galactosidase sur celle de la fermentation du lactose en milieu complexe dans le diagnostic bactériologique, en particulier des Enterobacteriaceae. Annales de l'Institut Pasteur, 102, 267-277.

O'Callaghan, C. H., Morris, A., Kirby, S. M., and Shingler, A. H. (1972). Novel method for detection of $\beta$-lactamases by using a chromogenic cephalosporin substrate. Antimicrobial Agents and Chemotherapy, 1, 283-288.

Richard, C. (1973). Etude antigénique et biochimique de 500 souches de Klebsiella. Annales de Biologie Clinique, 31, 297-303.

Zinnemann, K., and Biberstein, E. L. (1974). Genus Haemophilus. In Bergey's Manual of Determinative Bacteriology, 8th edition, edited by R. E. Buchanan and N. E. Gibbons, pp. 364-368. Williams \& Wilkins, Baltimore.

Zinnemann, K., Rogers, K. B., Frazer, J., and Bouyce, J. M. H. (1968). A new V-dependent Haemophilus species preferring increased $\mathrm{CO}_{2}$ tension for growth and named Haemophilus paraphrophilus, nov. sp. Journal of Pathology and Bacteriology, 96, 413-419.

Zinnemann, K., Rogers, K. B., Frazer, J., and Devaraj, S. K. (1971). A haemolytic V-dependent $\mathrm{CO}_{2}$ preferring Haemophilus species (Haemophilus paraphrohaemolyticus nov. spec.). Journal of Medical Microbiology, 4, 139-143.

Requests for reprints to: Dr W. Hansen, Service de Biologie Clinique, Hôpital Universitaire Brugmann, Avenue J.-J. Crocq 1, B-1020 Bruxelles, Belgium. 